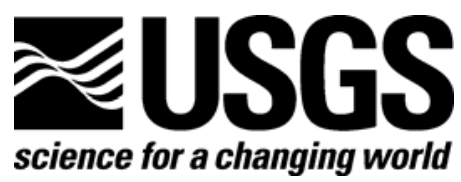

Pacific Island Ecosystems Research Center

\title{
An Analysis of the Risk of Introduction of Additional Strains of the Rust Puccinia psidii Winter ('Ohi`a Rust) to Hawai i
}

Lloyd Loope, US Geological Survey, Pacific Island Ecosystems Research Center, Makawao, Hawai i

and

Anne Marie La Rosa, USDA Forest Service, Institute of Pacific Islands Forestry, Hilo, Hawaii

Open File Report 2008-1008

U.S. Department of the Interior

U.S. Geological Survey 


\title{
U.S. Department of the Interior DIRK KEMPTHORNE, Secretary
}

\author{
U.S. Geological Survey \\ Mark D. Myers, Director
}

U.S. Geological Survey, Reston, Virginia 2008

For product and ordering information:

World Wide Web: http://www.usgs.gov/pubprod

Telephone: 1-888-ASK-USGS

For more information on the USGS - the Federal source for science about the Earth, its natural and living resources, natural hazards, and the environment:

World Wide Web: http://www.usgs.gov

Telephone: 1-888-ASK-USGS

Suggested citation:

Loope, Lloyd, and La Rosa, Anne Marie, 2008, An analysis of the risk of introduction of additional s trains of the rust puccinia psidii Winter ('Ohi'a Rust) to Hawai'i: U.S. Geological Survey Open-

File Report 2008-1008, 11 p. [http://pubs.usgs.gov/of/2008/1008/].

Any use of trade, product, or firm names is for descriptive purposes only and does not imply endorsement by the U.S. Government.

Although this report is in the public domain, permission must be secured from the individual copyright owners to reproduce any copyrighted material contained within this report. 


\section{An Analysis of the Risk of Introduction of Additional Strains of the Rust Puccinia psidii Winter ('Ohi`a Rust) to Hawai i}

By Lloyd Loope, US Geological Survey, Pacific Island Ecosystems Research Center, Makawao, Hawaìi(Lloyd_Loope@usgs.gov)

and

Anne Marie La Rosa, USDA Forest Service, Institute of Pacific Islands Forestry, Hilo, Hawai i (alarosa@fs.fed.us)

\section{An introduction to the problem of Puccinia psidii in Hawai i}

In April 2005, the rust fungus Puccinia psidii (most widely known as guava rust or eucalyptus rust) was found in Hawai $i$. This was the first time this rust had been found outside the Neotropics (broadly-defined, including subtropical Florida, where the rust first established in the 1970s). First detected on a nursery-grown `ohi'a plant, it became known as "ohi'a rust" in Hawai i (Killgore and Heu, 2007). The rust spread rapidly and by August 2005 had been found throughout the main Hawaiian Islands. The rust probably reached Hawai' $i$ via the live plant trade or via the foliage trade. In Hawai $i$, the rust has infected three native plant species and at least eight non-native species. Effects have been substantial on the endangered endemic plant Eugenia koolauensis and the introduced rose apple, Syzygium jambos. Billions of yellow, asexual urediniospores are produced on rose apple, but a complete life cycle (involving sexual reproduction) has not yet been observed (Uchida, 2007). The rust is autoecious (no alternate host known) on Myrtaceae. The strain introduced into Hawai $i$ is found sparingly on 'ohi`a (Metrosideros polymorpha), the dominant tree of Hawaii's forests, with sporadic damage detected to date. The introduction of a rust strain that causes widespread damage to ohi a would be catastrophic for Hawaii's native biodiversity. Most imports of material potentially contaminated with rust are shipped to Hawai $i$ from Florida and California (from which P. psidii was reported in late-2005 by Mellano, 2006). Florida is known to have multiple strains. The identity of the strain or strains in California is unclear, but one of them is known to infect myrtle, Myrtus communis, a species commonly imported into Hawai $i$. It is important to ecosystem conservation and commercial forestry that additional rust strains or genotypes be prevented from establishing in Hawai`i. 
The purpose of this analysis of risk is to evaluate the need for an interim rule by the Hawai' $i$ Department of Agriculture to regulate plant material of Myrtaceae arriving from the continental United States and to clarify consequences of such a rule, especially implications for possible eventual action by the U.S. Department of Agriculture, Animal and Plant Health Inspection Service, to assist in protection of Hawaii's native and non-native Myrtaceae from plant pests.

\section{Why does the rust have such a notorious reputation internationally?}

The eucalyptus rust (Puccinia psidii) is a pathogen with a very broad host range in the myrtle family (Myrtaceae). It was first described from common guava (Psidium guajava) in Brazil in the 1880s. It has been known to cause severe damage to nurseries and young Eucalyptus plantations in Brazil since the 1970s. Much concern has been expressed regarding the potential damage from Puccinia psidii. According to Ciesla and others (1996, p. 23), it is "regarded as the most significant quarantine risk to the cultivation of Eucalyptus spp. as well as to related plants. In Brazil it is severely limiting to the growth of highly susceptible species and provenances." Coutinho and others (1998, p. 824) noted that the potential pathogenicity of $P$. psidii seems to pose a "situation... equivalent to other introduced epidemic tree diseases, such as Dutch elm disease..., chestnut blight..., and white pine blister rust." Since its introduction to Hawai i, concern over possible establishment of $P$. psidii is especially high in Australia, a country with 1,300 species of endemic Myrtaceae. The pathogen may be particularly virulent on species with no evolutionary history of exposure (naïve hosts). For example, Glen and others (2007) state that "many non-native tree pathogens have been devastating after their introduction into new environments."

This rust has long been recognized as having a broad host range within the family Myrtaceae. The Neotropical genera of Myrtaceae recorded by Simpson and others (2006) as including one or more species attacked by P. psidii include Acca, Campomanesia, Eugenia, Marlierea, Myrcia, Myrcianthes, Myrciaria, Pimenta, and Psidium. Genera native outside the Neotropics and documented as attacked include Angophora, Callistemon, Corymbia, Eucalyptus, Eugenia, Heteropyxis, Kunzea, Melaleuca, Metrosideros, Myrtus, Syncarpia, and Syzygium (Simpson and others, 2006). Susceptibility to P. psidii is low among species of Myrtaceae from the Americas where $P$. psidii has long been present but seems to be high among "naïve" exotic genera and species from Asia, Australia and the Pacific (Simpson and others, 2006). Glen and others (2007) cites an Australian-Brazilian study (A.C. Alfenas and E.A.V. Zauza, unpubl. data; Tommerup and others, 2003) in which 58 Australian Myrtaceae species were exposed to P. psidii in Brazil; 52 of those had some degree of susceptibility.

\section{Does the rust damage native species of Myrtaceae in Florida or elsewhere in the United States?}

Myrtaceae is a tropical and Southern Hemisphere plant family. There are no native species of Myrtaceae in the United States other than in Florida and Hawai i, though non-native species such as bottlebrush (Callistemon spp.) and myrtle (Myrtus communis; native to the Mediterranean region) are cultivated in places like southern California. Florida has no endemic Myrtaceae but has 
eight native species of Myrtaceae that are also native further south in the Neotropics. Only one of those species (Myrcianthes fragrans) has been recorded as a host of the rust, and infection has apparently been minimal. An outbreak on introduced paperbark (Melaleuca quinquenervia) stands in South Florida in 1997 demonstrated its explosive virulence (Rayachhetry and others, 1997). Damage was substantial enough to consider using the pathogen as a biological control agent for paperbark in Florida (Grgurinovic and others, 2006). Melaleuca spp. are native to Australia and vicinity, and this pattern of infection is consistent with the theory that Australasian and Pacific Myrtaceae species that have evolved without exposure to $P$. psidii are more likely to be highly susceptible to serious damage from the rust than Neotropical species of Myrtaceae that evolved with exposure to the pathogen (Simpson and others, 2006).

\section{What is the current situation in Hawai i?}

Eucalyptus rust has been found statewide attacking Myrtaceae from sea level to about 1,200-m elevation in areas with rainfall ranging from 750-3,000 $\mathrm{mm}$. Three native and at least eight non-native species have been observed as hosts of $P$. psidii in Hawai' i, with the introduced and invasive rose apple (Syzygium jambos) being the most severely affected. Damage to rose apple has occurred at a landscape scale with widespread crown dieback. In spite of billions of winddispersed rust spores produced from rose apple infestations, adjacent 'ohi a have been little affected to date. The host distribution and preliminary work on the DNA profile suggest that only one genotype has been established in Hawai i (Shaobin Zhong, pers.comm., 2007; Anderson and others 2007; Zhong and others, 2007).

\section{What is a strain and what are the implications of strains?}

There is strong evidence of host specialization in this pathogen, with isolates from one host plant species not necessarily infecting other known host plant species. A rust population that is consistent in which host species it successfully attacks is termed a 'strain' (= race or biotype).

Glen and others (2007) summarize some of the complex findings on strains of $P$. psidii: "Several races or biotypes of $P$. psidii are known to exist ...very little is known of these specialized forms." Strains appear to differ in their host specificity, environmental tolerances, characteristics of sporulation and spore survival, and virulence. For example, two strains in Jamaica infected Pimenta spp. and Syzygium spp., respectively, but neither strain infected guava (MacLachlan, 1938). Three biotypes are known from Brazil (Glen and others, 2007). Much is still to be determined about strains and perhaps even taxonomy. "It is still not certain whether more than one species of Puccinia is capable of infecting members of the Myrtaceae" (Coutinho and others, 1998) and molecular comparisons are needed.

In Florida, the host range of this rust has increased over the past 30 years, possibly through the importation of additional rust strains (Leahy, 2004; J. Uchida, pers. comm., 2007). Its host range in Florida now includes about 20 native and introduced species. Specific strains from Florida have been characterized (Rayachhetry and others, 2001), and there is known to be substantial genetic variation (S. Zhong, pers. comm., 2007; Zhong and others, 2007). 
Even though the rust in Hawai $i$ was originally found on 'ohi'a, the primary species affected so far are rose apple (Syzygium jambos); paperbark (Melaleuca quinquenervia); and the endangered endemic Eugenia koolauensis. USDA-Agricultural Research Service in Maryland has verified (January 2006) that samples sent by Hawaii Department of Agriculture from Hawai'i, genetically conform to what they regard as the rose apple pathotype or strain. 'Ohi a has been sporadically affected by this strain. Species such as Eucalyptus spp. and allspice (Pimenta dioica), substantially damaged by $P$. psidii elsewhere in the world, have not been affected by the strain in Hawai i.

Preliminary information from DNA analysis of 12 P. psidii isolates collected on Oahu suggests that the $P$. psidii strain we have in Hawai $i$ has little genetic variation (S. Zhong, pers. comm.., 2007). No sexual stage is known from Hawai i (J. Uchida, pers. comm.., 2007). The host distribution and DNA profile results suggest that only one genotype has been established in Hawai i. (S. Zhong, pers. comm., 2007; Anderson and others, 2007; Zhong and others, 2007). This is in contrast to the considerable genetic variation found in the Florida rust.

\section{What is the threat to Hawai i from additional strains of $P$. psidit?}

According to the treatment by Dawson and Stemmerman (1990), Hawai i has seven endemic Myrtaceae: Eugenia koolauensis (Endangered), E. sandwicensis, Metrosideros macropus, $M$. polymorpha (9 varieties), M. rugosa, M. tremuloides, and M. waialealae (3 varieties), all endemic to the Hawaiian Islands. The substantial effect on the endangered E. koolauensis has been noted above. By far the most notable concern for damage by additional rust strains is to 'ohi`a, $M$. polymorpha, a major component of the native forest on all major islands of the Hawaiian archipelago. This single species overwhelmingly dominates approximately 80 percent of Hawai'i's remaining native forest or about 965,000 acres (1,500 square miles).

\section{Threat to Hawaiian forests}

Since 'ohi'a is the dominant tree in most of Hawai'i's forests, a continuing outbreak on 'ohi`a, similar to that observed on rose apple, could result in significant changes to the structure, composition, and potentially, the function, of forests on a landscape level. Many (one-third to onehalf) of Hawai i's approximately 300 endangered plant species also depend on critical habitat in Metrosideros polymorpha forest. Eucalyptus rust is most damaging to young, developing tissue. Though "evergreen," individual leaves of 'ohi a trees last 1.5-2.5 years (Cordell and others, 2001), so require continual replacement. Destruction of new 'ohi`a growth would cause not only crown dieback but likely result in low reproduction (few mature flower buds, young fruit). 'Ohi`a seedlings would also be severely damaged, further reducing reproduction. Eventually, repeated, severe crown dieback could result in the death of trees as food reserves are used up and no new photosynthetic tissue is added. Increased light reaching the forest floor following canopy dieback would increase the likelihood of invasion by light-loving non-native species, such as Miconia calvescens and introduced grasses. Increases of certain non-native plants have been shown to cause changes in ecosystem function, for example nitrogen cycling (Hughes and Denslow, 2005). Watershed impacts are also possible with a rapid loss of overstory. 


\section{Threat to Agriculture}

Plantations of Eucalyptus saligna, E. robusta, and E. grandis, varying in age from 15 to 60 years, are grown commercially on approximately 20,000 acres of private and 8,000 acres of stateowned lands. Although E. saligna and E. robusta are known hosts for the disease, commercial Eucalyptus forests in Hawai i have not yet been affected. Many of these acres are scheduled for thinning or harvesting in the next 1 to 2 years, and if replanted, could result in many acres of seedling and sapling Eucalyptus being available for infection. The use of genetically resistant stock could help alleviate the risk, as has been done with much success in Brazil (Coutinho and others, 1998).

\section{Threat to Hawaiian culture}

The dominant tree in the Hawai $\mathrm{i}$ islands, 'ohi a is a species of major cultural significance to the Hawaiian people. Many native plants and animals that depend on 'ohi'a forests have cultural significance, but 'ohi'a stands out as having special symbolic and spiritual significance via its connection to the deities $\mathrm{Ku}$, Pele and Laka, as well as obvious material significance. For example, as the native plant symbol of Laka, the deity of hula, 'ohi'a is central to a large number of chants and dances, and its loss would affect the spiritual significance of hula and chant (Samuel Gon, III, pers. comm., 2006).

\section{Threat to Hawaiian fauna, including Hawaiian honeycreepers}

'Ohi'a is a major component of montane and lowland wet, mesic and dry forests that are home to one native mammal (Hawaiian hoary bat) and 30 species of forest birds (Hawai i Department of Land and Natural Resources, 2005). A spectacular land bird assemblage, the Hawaiian honeycreepers, an endemic subfamily (Fringillidae: Drepanidinae), evolved in the Hawaiian Islands (Freed and others, 1987). Although over 65 percent of the species are extinct, the remaining species still provide an impressive example of adaptive radiation among birds. Eighteen of 19 extant Hawaiian honeycreepers in the main Hawaiian islands, including 12 of 13 species listed as endangered by the U.S. Fish and Wildlife Service, depend on 'ohi' a for critical habitat. Most surviving honeycreeper species inhabit `ohi`a or `ohi`a/koa forests. The continuing decline of honeycreepers and other Hawaiian birds is believed to be largely a result of habitat loss, susceptibility to introduced bird diseases, predation by introduced mammals, competition from introduced birds, and reduction in abundance of arthropod food items (Scott and others, 1986, Jacobi and Atkinson, 1995). Significant degradation of Hawai `i’s `ohi`a forest by Puccinia psidii would negatively affect opportunities for survival of endangered honeycreepers as well as populations of some non-endangered species (anianiau, Kauai creeper, Maui creeper, and i’iwi), making them more likely to become endangered.

Many endemic Hawaiian invertebrates also are dependent upon `ohi`a or `ohi`a/koa forests. Over 90 percent of the more than 5,000 known terrestrial invertebrate species are endemic. These species are important as bird food and pollinators of both native and introduced plants. The 
primary threat to invertebrates is the loss of habitat (Hawai' i Department of Land and Natural Resources, 2005). As with birds, the loss of `ohi`a would have significant negative repercussions on these taxa.

\section{Recurrent outbreak, Hawai i-wide, on rose apple}

Beginning in January 2006, a severe outbreak of $P$. psidii rust became apparent statewide, affecting new leaves of rose apple. Since its introduction to Hawai i about 1825, rose apple (an ornamental tree native to south and southeast Asia) has become widespread in wet and mesic lowland sites to about 1,000-m elevation. As of April 2007, this outbreak is killing new leaves of rose apple throughout the islands. Large patches of red-brown vegetation ( $S$. jambos) are sufficiently conspicuous to elicit curiosity in even the most casual observer. The dramatic effect of the rust on rose apple vividly illustrates the potential virulence of this rust. This host is so far the most visible example of a "naïve host." The fate of these trees in Hawai'i is unknown, though heavy mortality is expected in areas such as East Maui with a high occurrence of rose apple (Loope, pers. obs.), but rose apple trees on the campus of the University of Brasilia seem to persist in spite of substantial damage annually (Tessmann and others, 2001).

\section{What are the pathways for entry of Puccinia psidii into Hawai i?}

There are several pathways by which Puccinia psidii could reach Hawai i from infected areas. These pathways have been described for Australia (Grgurinovic and others, 2006). Uredineospores of $P$. psidii can remain viable for at least two months outside hosts under suitable environmental conditions (Grgurinovic and others, 2006). Potential pathways include:

- High risk material of Myrtaceae species: movement of host plants, germ plasm and plant products, including seed and pollen, micro propagation material and tissue culture, cuttings and live plants, and lumber, wood chips and dunnage;

- Unregulated movement of plant material: undeclared seed, nursery stock, etc.;

- Movement of people: as contaminants on clothing and luggage of people traveling from infested areas; and

- Long distance dispersal by air currents.

Although a lot is known about the rust and the threat it poses, our knowledge about pathways has been and continues to be imperfect. For example, we do not know precisely how and from where Hawaii's existing strain was introduced. The most current knowledge suggests that the most likely pathway of entry of Puccinia psidii into Hawai i is via nursery stock or foliage of Myrtaceae. Puccinia psidii is widely distributed in south Florida and has been established on myrtle (Myrtus communis) in San Diego County, California, since November 2005 (Mellano, 2006). Shipments of myrtle commonly come to Hawai i from California (Janice Uchida, former flower shop owner, pers. comm., 2007); therefore this is a likely source of infection. Maui inspectors intercepted the rust on myrtle from a small town California shipper in December 2006. Timothy Tidwell, Plant Pathologist with the California Department of Food and Agriculture, stated 
in a 17 April email: "We have detected this rust species from samples originating from San Diego on Eugenia myrtifolia, and what appears to be an interception on unspecified nursery stock shipped from FL. We also have a record of it from LA on an intercepted shipment of allspice plants (Pimenta dioica)."

Further delineation of the movement of plants and plant materials to Hawai $i$ from locations known to have the rust will be helpful in establishing permanent regulations. In 2004, Australia suspended trade in Eucalyptus timber from areas known to have the rust following a positive identification of P. psidii spores on new sawn Eucalyptus timber (Grgurinovic and others, 2006).

\section{Why is this situation an emergency warranting an interim rule?}

The potential harm to Hawaii's native forest ecosystems and plantations of a virulent strain of $P$. psidii to 'ohi' a and the existence of additional strains in locations along known trade pathways with Hawai i (Florida and California) warrant prompt and effective measures to prevent the arrival of other P. psidii strains.

An import moratorium on all plants and plant parts of Myrtaceae from areas known to have Puccinia psidii will allow improvements of quarantine and specific mitigations of pest risks until further information can be gathered on host susceptibility to additional strains.

Establishment and behavior during the past two years of Hawai i's first $P$. psidii strain demonstrates that this rust species thrives in Hawai i's environment, spreads long distances by the wind, and can severely damage an abundant and susceptible species, as it has done with rose apple. The risk is high for arrival of and damage from new strains.

The latest (preliminary) information from DNA analysis (S. Zhong, pers.comm. 2007; Zhong and others, 2007) suggests that we have a single $P$. psidii strain in Hawai $i$ and that strain has low genetic variability. A complete life cycle (involving sexual reproduction) has not yet been observed in Hawaii (Uchida, 2007). If this is indeed an asexual strain, its probability of mutating and posing serious damage to 'ohi'a is considerably less than if a sexual strain or multiple strains were present.

While there appears to be little genetic variability in the current genotype in Hawai $i$, there is much variability within different strains present elsewhere. With genetic recombination accompanying sexual reproduction of a new strain and with hybridization among strains, the likelihood of a genotype arising that can damage 'ohi'a is greatly increased (Brasier, 2001; Wingfield, 2001: Wingfield and others, 2003; and Richardson and others, 2005).

An ideal environment for the rust, a moist tropical and montane tropical climate, exists in Hawai i. 'Ohi 'a, is dominant in 80 percent of the state's forests. Naïve (new) Myrtaceae hosts for $P$. psidii in the Pacific region are likely to be more susceptible than Myrtaceae native to Neotropical locations, where the rust is also native. 
Puccinia psidii cannot be controlled in the wild once introduced. Limited control is available for nurseries. Quarantine restrictions are the only opportunity to prevent introduction of a potentially virulent strain.

\title{
What is the role of the U.S. Department of Agriculture (APHIS) in preventing additional strains of Puccinia psidii into Hawai i from other countries? (Contributed by Dorothy Alontaga, USDA-APHIS, Honolulu)
}

\begin{abstract}
APHIS regulates plants and plant parts imported from foreign countries. A few of the hosts of the rust are prohibited from most countries. Some of the hosts of the rust are restricted in some way (e.g., Post-Entry) from certain countries. There are gaps in the protection because not all hosts from potential source countries are prevented entry as propagative material and not all hosts from source countries are prevented as non-propagative plants parts. For example, APHIS regulates foreign importation of plants as cut flowers and foliage. Currently, APHIS does not prohibit or restrict the rust hosts imported as material not capable of propagation. Secondly, APHIS determines the quarantine significance of pests. Some pests require quarantine action; others do not.
\end{abstract}

Requests for further restriction of Myrtaceae in foreign import quarantines, based on the risk of introducing new strains of Puccinia psidii, would be directed to APHIS. However, currently $P$. psidii is known to occur in the United States and is categorized (by APHIS) as a non-reportable pest at the species level. The status does not distinguish between strains of $P$. psidii. This is important because APHIS would not regulate Myrtaceae for a non-reportable pest. A key factor to consider for changes to the pest status of $P$. psidii involves the obligations of the United States as a signatory of the International Plant Protection Convention (IPPC). The IPPC definition of quarantine pest is: "Quarantine pest' - a pest of potential economic importance [this includes environmental impact] to the area endangered thereby and not yet present there, or present but not widely distributed and being officially controlled." The implication for prevention of P. psidii strains is to meet the pest definitions of limited distribution and official control. This is why state quarantine is important not only for protection from domestic movement, but also important for making progress for changes in regulation of foreign imports. If there are no state quarantine controls, the pest will not meet the IPPC definition of a quarantine pest.

Even if foreign import into Hawaii is restricted, restriction of domestic movement of Myrtaceae from the U.S. mainland will still play the major role in prevention of arrival of new strains of the rust. This is because APHIS restrictions on Myrtaceae and the reportability of the rust for Hawai'i would be most effective for plant material entering Hawai'i as the first port of entry. The pest would remain non-reportable to the other states where there is no official control. Major ports of entry for foreign plant material from major infestation areas in Central America, South America, and the Caribbean are the large mainland ports such as Los Angeles and Miami. There are no regular flights directly into Hawaii from these countries. Having entered the United States at one of the large ports, these shipments could then enter Hawai'i as domestic movement. Hawai' $i$ regulation of Myrtaceae through state quarantine is a necessary prerequisite to pursuit of change in 
federal quarantine (APHIS) and is the only option for overall protection from future strains of $P$. psidii.

\section{What are the expected economic impacts of an interim rule?}

A moratorium on the importation of Myrtaceae plants and plant parts into Hawaii would have both positive and negative economic impacts. For businesses centered on existing native or non-native Myrtaceae already in Hawaii, such as the non-native Eucalyptus forest industry, the status quo would be maintained with positive or neutral economic impacts anticipated. Many of the 28,000 acres of Eucalyptus plantations in Hawai $i$ are scheduled for harvest in the next couple of years and replacement seedlings and saplings are potentially vulnerable to new strains of the rust. The eucalyptus forest industry in Hawai i has not yet been affected by the rust, and prevention of rust damage would benefit this section of the forest industry. For businesses involved in the importation of Myrtaceae plants and plant parts, some negative economic impacts would be anticipated. Although the volume of Myrtaceae foliage and perhaps live plants coming into Hawai i may be substantial, the overall economic impact of restrictions on Myrtaceae imports to Hawai $\mathrm{i}$ is expected to be small. This expectation is based on the assumption that other products

can and will be substituted for Myrtaceae in the foliage trade and that Myrtaceae probably provides only a very small part of the Hawai i market for live plants. In the long run, it is expected that myrtaceous plants and foliage to be used in Hawai i can be grown in Hawai $i$ and the potential for new local industries may offset losses experienced from a restriction on imports. We expect that additional information on economic impacts will come to light in the near future in response to an interim rule.

\section{References Cited}

Anderson, R., Uchida, J., and Loope, L., 2007, Establishing a baseline: Assessment of hosts, effects, and climatic range of Hawai i's current strain of Puccinia psidii. Abstract submitted for 2007 Hawai i Conservation Conference, July 25-27, 2007.

Brasier, C.M., 2001, Rapid evolution of introduced plant pathogens via interspecific hybridization: BioScience v. 51, p.123-133.

Ciesla, W.M., Diekmann, M., and Putter, C.A.J.,1996, FAO/IPGRI Technical Guidelines for the Safe Movement of Germplasm, No. 17: Eucalyptus spp., United Nations Food and Agriculture Organization and International Plant Genetic Resources Institute, 66 p. http://www.bioversityinternational.org/fileadmin/bioversity/publications/pdfs/406.pdf

Cordell, S., Goldstein, G., Meinzer, F.C., Vitousek, P.M., 2001, Regulation of leaf life-span and nutrient-use efficiency of Metrosideros polymorpha trees at two extremes of a long chronosequence in Hawai i: Oecologia, v. 127, p. 198-206.

Coutinho, T.A., M.J. Wingfield, A.C. Alfenas, and P.W. Crous. 1998. Eucalyptus rust: a disease with the potential for serious international implications. Plant Disease 82:819-825. 
Dawson, J.W., and Stemmerman, L., 1990, Metrosideros, in Wagner, W.L., Herbst, D.R., and Somer, S.H., eds., Manual of the Flowering Plants of Hawai i, Vol. 1: Honolulu, University of Hawai i Press, p. 964-970.

Freed, L.A., Conant, S., and Fleischer, R.C., 1987, Evolutionary ecology and radiation of Hawaiian passerine birds: Trends in Ecology and Evolution, v. 2, p.196-203.

Glen, M., Alfenas, A.C., Zauza, E.A.V., Wingfield, M.J. and Mohammed C., 2007, Puccinia psidii: a threat to the Australian environment and economy - a review: Australasian Plant Pathology v. 36, no. 1, p.1-16.

Grgurinovic, C.A., Walsh, D., and Macbeth, F., 2006, Eucalyptus rust caused by Puccinia psidii and the threat it poses to Australia: EPPO Bulletin v. 36, no. 3, p. 486-489.

Hawai i Department of Land and Natural Resources, 2005, Hawai i Comprehensive Wildlife Conservation Strategy, October 2005. 734 p.

Hughes, R.F. and J.S. Denslow. 2005. Invasion by an $\mathrm{N}_{2}$-fixing tree alters function and structure in wet lowland forests of Hawai i: Ecological Applications v.15, no. 5, p. 1615-1628.

Jacobi, J.D., and Atkinson, C.T., 1995, Hawai i's endemic birds, pages 376-381 in LaRoe, E.T., and others, Our Living Resources, U.S. Department of the Interior, National Biological Service, Washington, D.C., $530 \mathrm{p}$.

James, H.F., and S.L. Olson. 1991. Descriptions of thirty-two new Species of Hawaiian birds. Part II. Passeriformes. Ornithological Monographs, no. 46, Smithsonian Institution. Washington, DC.

Killgore, E.M. and R.A. Heu. 2007. Ohi`a rust. Puccinia psidii Winter. New Pest Advisory No. 0504. Hawaii Department of Agriculture. Updated March 2007.

Leahy, R. 2004. Recent History of Puccinia psidii on Myrtaceae in Florida by Robert Leahy, Plant Pathologist -FDACS-DPI. http://pestalert.ifas.ufl.edu/tmm-0209.htm

MacLachlan, J.D., 1938, A rust of the pimento tree in Jamaica, BWI: Phytopathology, v. 28, p. $157-170$.

Mellano, V, 2006, Rust on myrtle found in San Diego County. Healthy Garden-Healthy Home, University of California Cooperative Extension: Retail Nursery Newsletter, v. 1, Issue 6, p. 3.

Rayachhetry, M.B., Elliot, M.L., and Van, T.K., 1997, Natural epiphytotic of a rust fungus (Puccinia psidii) on Melaleuca quinquenervia in Florida: Plant Disease, v. 81, p. 831.

Rayachhetry, M.B., Van, T.K., Center, T.D., and Elliott, M.L., 2001, Host range of Puccinia psidii, a potential biological control agent of Melaleuca quinquenervia in Florida: Biological Control, v. 22 , p. 38-45. 
Richardson, B., N.B. Klopfenstein, and T.L. Peever. 2005. Assessing forest-pathogen interactions at the population level, p. 21-30, In Forest pathology: From genes to landscapes, edited by J.E. Lundquist and R.C. Hamelin. APS Press. The American Phytopathological Society, St. Paul, Minnesota.

Scott, J.M., Mountainspring, S., Ramsey, F.L., and Kepler, C.B., 1986, Forest bird communities of the Hawaiian islands: their dynamics, ecology and conservation: Studies in Avian Biology, v. 9, p. $1-431$.

Simpson, J.A., Thomas, K., and Grgurinovic, C.A., 2006. Uredinales species pathogenic on species of Myrtaceae: Australasian Plant Pathology, v. 35, p. 546-562.

Tessmann, D.J., Dianese, J.C., Miranda, A.C., and Castro, L.H.R., 2001, Epidemiology of a Neotropical rust (Puccinia psidii): periodical analysis of the temporal progress in a perennial host (Syzygium jambos): Plant Pathology, v. 50, p. 725-731.

Tommerup, I.C., Alfenas, A.C., and Old, K.M., 2003, Guava rust in Brazil -- a threat to eucalyptus and other Myrtaceae: New Zealand Journal of Forestry Science, v. 33, no. 3, p. 420428.

Uchida, J.Y., 2007, Pathogenicity and biology of Puccinia psidii in Hawai'i. Abstract for 2007 Hawaii Conservation Conference, July 25-27, 2007.

Wingfield, M.J., 2003, 2003 Daniel McAlpine Memorial Lecture, Increasing threat of diseases to exotic plantation forests in the Southern Hemisphere: lessons from Cryphonectria canker: Australasian Plant Pathology, v. 32, p.133-139.

Wingfield, M.J., Slippers, B., Roux, J., and Wingfield, B.D., 2001, Worldwide movement of exotic forest fungi, especially in the tropics and the Southern Hemisphere: BioScience, v. 51, p. 134140.

Zhong, S., Yang, B., and Alfenas, A.C., 2007, Development of microsatellite markers for the guava rust fungus, Puccinia psidii: Molecular Ecology Notes doi: 10.1111/j.14718286.2007.01952.x) 